\begin{tabular}{|l|l|l||}
\hline \multicolumn{2}{|c|}{ PublisherInfo } \\
\hline \hline PublisherName & $:$ & BioMed Central \\
\hline \hline PublisherLocation & $:$ & London \\
\hline \hline PublisherImprintName & $:$ & BioMed Central \\
\hline \hline
\end{tabular}

\title{
Turning off a transgene
}

\begin{tabular}{|l|l|l||}
\hline \multicolumn{2}{|c|}{ ArticleInfo } \\
\hline \hline ArticleID & $:$ & 4537 \\
\hline \hline ArticleDOI & $:$ & $10.1186 /$ gb-spotlight-20020723-01 \\
\hline \hline ArticleCitationID & $:$ & spotlight-20020723-01 \\
\hline \hline ArticleSequenceNumber & $:$ & 203 \\
\hline \hline ArticleCategory & $:$ & Research news \\
\hline ArticleFirstPage & $:$ & 1 \\
\hline \hline ArticleLastPage & $:$ & 2 \\
\hline \hline & & RegistrationDate : 2002-7-23 \\
\hline ArticleHistory & $:$ & OnlineDate \\
\hline \hline ArticleCopyright & $:$ & BioMed Central Ltd2002-7-23 \\
\hline \hline ArticleGrants & $:$ & \\
\hline \hline ArticleContext & $:$ & 130593311 \\
\hline \hline
\end{tabular}




\section{Jonathan B Weitzman}

Email: jonathanweitzman@hotmail.com

DNA methylation is thought to play an important role in gene silencing and epigenetic regulation in plants. In the Early Edition of the Proceedings of the National Academy of Sciences, Kloti et al. describe a useful transgenic model for investigating the link between methylation and silencing. They studied a line of transgenic rice plants in which a $\beta$-glucuronidase (GUS) reporter gene, under control of the rice tungro bacilliform virus (RTBV) promoter, becomes inactivated in a progressive and tissuespecific manner. Some transgenic lines showed reproducible loss of GUS gene expression in vascular cells in the first homozygous generation. The methylation spread in subsequent generations, causing complete repression. The transgene could be re-activated by treatment with the methylation inhibitor 5 -azacytidine. Kloti et al. found that methylation of the RTBV promoter resulted in the association of a sequence- and methylation-specific DNA-binding protein.

\section{References}

1. Gene silencing and DNA methylation processes

2. Proceedings of the National Academy of Sciences, [http://www.pnas.org] 